\title{
Changes in soil microbial community and enzyme activity along an exotic plant Eupatorium adenophorum invasion in a Chinese secondary forest
}

\author{
SUN Xin ${ }^{1,2}$, GAO Cheng ${ }^{1,2} \&$ GUO LiangDong ${ }^{1 *}$ \\ ${ }^{1}$ State Key Laboratory of Mycology, Institute of Microbiology, Chinese Academy of Sciences, Beijing 100101, China; \\ ${ }^{2}$ University of Chinese Academy of Sciences, Beijing 100049, China
}

Received February 23, 2013; accepted April 24, 2013; published online July 25, 2013

\begin{abstract}
The exotic plant, Eupatorium adenophorum, has invaded rapidly across southwest China, damaging native ecosystems and causing great economic losses. Soil microbes, as an important component of belowground community, can drive nutrient cycling and regulate plant competition in terrestrial ecosystems. Therefore, knowledge of the soil microbial community and function will enhance our understanding of the mechanism of exotic plant invasive process in natural ecosystems. In this study, we examined the soil microbial community, soil enzyme activity, soil property and plant community along an invasive gradient of E. adenophorum in a southwest Chinese secondary forest. The soil analysis demonstrated that heavy invasion significantly increased the total $\mathrm{P}$ and $\mathrm{NO}_{3}^{-}-\mathrm{N}$ contents, whereas it significantly decreased the total $\mathrm{N}$ and soil organic matter contents. The available $\mathrm{P}$ content was significantly decreased by moderate invasion. The E. adenophorum invasion significantly decreased the biomass of total soil microbes, as well as Gram-negative bacteria, actinomycetes, arbuscular mycorrhizal (AM) fungi and non-AM fungi. However, $E$. adenophorum invasion significantly increased the activities of soil urease, acid phosphatase, polyphenol oxidase and peroxidase. Non-metric multidimensional scaling showed that soil microbial composition and soil enzyme composition were significantly different in the three E. adenophorum invaded sites. Partial Mantel tests indicated that plant composition was the most important factor for structuring soil microbial and enzyme compositions. The results suggest that changes in soil microbial community structure and enzyme activity may play an important role in the process of E. adenophorum invasion in a Chinese secondary forest ecosystem.
\end{abstract}

Crofton weed, invasion density, microbial biomass, community composition, enzyme activity

Citation: Sun X, Gao C, Guo L D. Changes in soil microbial community and enzyme activity along an exotic plant Eupatorium adenophorum invasion in a Chinese secondary forest. Chin Sci Bull, 2013, 58: 4101-4108, doi: 10.1007/s11434-013-5955-3

Rapid expansion of invasive plants is threatening biodiversity, productivity, and ecosystem health throughout the world [1,2]. Understanding the strategies employed by invasive plants for rapid spread is one of the most important fields in ecology. Although multiple hypotheses have been put forward to explain the remarkable success of many invasive plant species, most of these studies have mainly focused on aboveground features [3]. As an important component of belowground community, soil microbes can drive nutrient cycling and regulate plant competition in terrestrial

*Corresponding author (email: guold@sun.im.ac.cn) ecosystems [4,5], they therefore can play an important role in driving plant invasion $[5,6]$.

An increasing number of studies have shown that exotic invasive plants can influence the abundance, composition and functioning of soil microbial communities [6-13]. Furthermore, these changes in soil communities usually promote the growth of invasive plants, yet inhibit native plant performance, mainly driven by the lack of soil pathogens to invasive plants in the new habitats $[14,15]$, the preferential enrichment of microbial pathogens to native plants [16,17], or the inhibition of microbial mutualism with native plants [18-20]. 
Eupatorium adenophorum Spreng. (croftonweed), native to Mexico and Costa Rica of Central America, is a worldwide invasive weed. This plant has invaded southwest China since the 1940s and become one of the most noxious invaders, damaging native ecosystems and causing great economic losses in China [21,22]. Several mechanisms have been proposed to explain the success of E. adenophorum invasion, such as rapid genetic differentiation [23], extraordinary biological characteristics including high seed production and germination [24,25], wide biogeographic adaptation [26,27], and production of allelopathic compounds that reduce native plant growth [28-30]. However, little information has been available on the responses of soil microbial community structure and function to E. adenophorum invasion, except for a few studies of its effect on soil bacterial composition [31,32].

In order to understand the response of soil microbial community structure and function to E. adenophorum invasion, in this study we selected three invasive intensities of $E$. adenophorum in a secondary forest of Yunnan Province, southwestern China. The soil microbial communities were examined based on the analysis of phospholipid fatty acids (PLFA). Soil enzyme activities concerning the cycling of carbon $(\mathrm{C})$, nitrogen $(\mathrm{N})$ and phosphorus $(\mathrm{P})$ were tested, and soil characteristics and plant community were investigated. The objectives were to (1) explore how the soil microbial community and enzyme activity change along a Eupatorium adenophorum invasion gradient, and (2) find out the important factors that affect soil microbial community and enzyme compositions during the E. adenophorum invasion in a Chinese secondary forest.

\section{Materials and methods}

\subsection{Study site and sampling}

The study was conducted in an evergreen mixed forest in Xishan of Kunming, Yunnan Province, southwest China $\left(24^{\circ} 58^{\prime} 33.1^{\prime \prime} \mathrm{N}, 102^{\circ} 37^{\prime} 04.9^{\prime \prime} \mathrm{E}\right)$, with an average elevation of $2200 \mathrm{~m}$ above sea level, a mean annual precipitation of $932.7 \mathrm{~mm}$, and a mean annual temperature of $15.6^{\circ} \mathrm{C}$. This location used to be dominated by the native plant community, but has been invaded by $E$. adenophorum for the last 30 years. The location is southwest-facing with an average slope of $25^{\circ}$. The E. adenophorum invasion has obviously started from roadside to hillside with different displacement intensities, i.e. the cover of E. adenophorum decreased from the roadside to hillside. Three sites with different covers of E. adenophorum were selected. The first site was not invaded by $E$. adenophorum (hereafter referred to as NI). There were about 18 plant species, including three woody trees, 12 shrubs and three grasses in this site dominated by Myrsine africana with an average cover of 59\%. The second site, with 40\%-50\% cover of E. adenophorum, was termed as the moderately invaded site (MI). There were about 19 plant species, including four woody trees, 12 shrubs and three grasses in this site. The third site, with more than $70 \%$ cover of E. adenophorum, was termed as the heavily invaded site (HI). There were about 16 plant species, including four woody trees, nine shrubs and three grasses. The distances between the sites were more than $100 \mathrm{~m}$.

Three plots $(20 \mathrm{~m} \times 20 \mathrm{~m}$ each $)$ were randomly set in each site and the distances between plots were more than $100 \mathrm{~m}$. Five composite soil samples, each consisting of three soil cores $(3.5 \mathrm{~cm}$ in diameter, $15 \mathrm{~cm}$ deep), were randomly collected from each plot in April, 2008. The soil samples were immediately transported to the laboratory and sieved (2-mm mesh) to remove plant roots and debris. A part of fresh soil ( $c$. $20 \mathrm{~g}$ each sample) was stored at $-80^{\circ} \mathrm{C}$ for PLFA analysis. The remaining soil samples ( $c a .300 \mathrm{~g}$ ) were stored at $4{ }^{\circ} \mathrm{C}$ or air-dried according to the requirement of analyses of soil characteristics and soil enzyme activities.

\subsection{Soil characteristics}

The soil organic matter (SOM) was determined using $\mathrm{K}_{2} \mathrm{Cr}_{2} \mathrm{O}_{7}-\mathrm{H}_{2} \mathrm{SO}_{4}$ oxidation method [33]. Total nitrogen (N) was measured using the Kjeldahl method [34]. Soil mineral $\mathrm{N}$ was extracted with $2 \mathrm{~mol} \mathrm{~L}^{-1} \mathrm{KCl}$, then the concentrations of $\mathrm{NO}_{3}^{-}-\mathrm{N}$ and $\mathrm{NH}_{4}^{+}-\mathrm{N}$ in the $\mathrm{KCl}$ extracts were determined by hydrazine sulfate colorimetry and indophenol blue colorimetry, respectively [35]. The total phosphorus (P) and available $\mathrm{P}$ were determined using the colorimetric Moblue-method [36]. The $\mathrm{pH}$ value $(1: 2.5$ solution, soil to water) was measured using a Glass Electrode-calomel Electrode $\mathrm{pH}$ meter (Mettler-Toledo International Inc., China).

\subsection{PLFA analysis}

PLFAs were analyzed following a procedure described by Frostegård et al. [37]. Briefly, lipids were extracted from $4.0 \mathrm{~g}$ of freeze-dried soil with a chloroform: methanol:citrate buffer mixture $(1: 2: 0.8, \mathrm{v} / \mathrm{v} / \mathrm{v})$, and the lipids were separated into neutral lipids, glycolipids and phospholipids on a silicic acid column. Phospholipids were then converted to fatty acid methyl esters by mild alkaline methanolysis. Fatty acid methyl esters were analyzed using a gas chromatograph (GC 7890, Agilent Technologies, Inc., USA) coupled with a mass spectrometer (5973N MSD, Agilent Technologies, Inc., USA). The individual fatty acid peaks were quantified based on peak area converted to nmol lipid $\mathrm{g}^{-1}$ soil DW using methyl nonadecanoate fatty acid (19:0) as an internal standard. Fatty acids were designated in terms of total number of carbon atoms: number of double bonds, followed by the position of the double bond from the methyl end $(\omega)$ of the molecule. The prefixes ' $i$ ' and ' $a$ ' indicate iso- and anteiso branching, 'br' indicates an unknown methyl branching position, 'cy' indicates cyclopropane fatty acid, and 'Me' refers to the position of methyl group from the carboxyl end of the chain. 
The sum of PLFAs with no more than 20 carbon atoms in length was used to calculate total microbial biomass [38]. Furthermore, we used a sum of indicative PLFAs to represent the biomass of different microbial groups, including Gram-negative bacteria $\left(\mathrm{G}^{-}\right)$[39], Gram-positive bacteria $\left(\mathrm{G}^{+}\right)$[39], actinomycetes [10,37], arbuscular mycorrhizal fungi (AMF) [40], and fungi (excluding AMF) [38,41].

\subsection{Soil enzyme activity}

The activities of eight enzymes which are related to the cycling of $\mathrm{C}, \mathrm{N}$, and $\mathrm{P}$ were measured in this study, including $\beta$-glucosidase (E.C. 3.2.1.21), invertase (E.C. 3.2.1.26), cellulase (E.C. 3.2.1.4), urease (E.C. 3.5.1.5), acid phosphatase (E.C. 3.1.3.2), alkaline phosphatase (E.C. 3.1.3.1), polyphenol oxidase (E.C. 1.10.3.1), and peroxidase (E.C. 1.11.1.7).

$\beta$-glucosidase and phosphatase activities were measured using the p-nitrophenol (pNP) method [42]. The substrates were pNP- $\beta$-D-glucopyranoside for $\beta$-glucosidase and pNP-phosphate for acid phosphatase and alkaline phosphatase. The urease activity was determined using urea as substrate, and the soil mixture was incubated at $37^{\circ} \mathrm{C}$ for $5 \mathrm{~h}$. The residual urea was determined by a colorimetric method [43]. Cellulase and invertase activities were analyzed using CM-cellulose and sucrose as substrates, respectively, following the method described by Schinner and von Mersi [44]. Polyphenol oxidase activity was determined using pyrogallol as substrate and oxidation products were determined colorimetrically at $430 \mathrm{~nm}$ [45]. Peroxidase activity was determined using pyrogallol and hydrogen peroxide as substrates following the same procedure as measure of polyphenol oxidase activity.

\subsection{Data analysis}

The sum of indicative PLFAs that represent different taxonomic microbial groups was used instead of individual PLFA data to visualize the real status of soil microbial composition [46]. One-way analysis of variance (ANOVA) followed by a Least Square Difference (LSD) post hoc test was carried out to explore the differences in soil characteristic variables $\left(\mathrm{SOM}\right.$, Total $\mathrm{N}, \mathrm{NO}_{3}{ }^{-}-\mathrm{N}, \mathrm{NH}_{4}{ }^{+}-\mathrm{N}$, total $\mathrm{P}$, available $\mathrm{P}$, and $\mathrm{pH}$ ), biomass of total soil microbes and every microbial group $\left(\mathrm{G}^{+}, \mathrm{G}^{-}\right.$, actinomycetes, $\mathrm{AMF}$, and fungi) and soil enzyme activities ( $\beta$-glucosidase, invertase, cellulase, urease, acid phosphatase, alkaline phosphatase, polyphenol oxidase, and peroxidase) among the three $E$. adenophorum invaded sites. To assure normality and homogeneity of PLFA and enzyme activity data, PLFA data were $\log \left(x_{i}+1\right)$ transformed, and soil enzyme activity data were $x_{i} / x_{\text {mean }}$ standardized in ANOVA analysis.

Distance matrices of soil microbial community (PLFA content dataset, wisconsin-sqrt transformed) and soil enzyme composition (enzyme activity datasets, wisconsin-sqrt transformed) were generated by calculating Bray-Curtis dissimilarity. Non-metric multidimensional scaling (NMDS) was carried out to visualize the distance matrices of soil microbial composition and soil enzyme composition of all plots. Eupatorium adenophorum invasion intensity were fitted as centroids, and soil characteristic variables and plant species were fitted as vectors onto the ordination plots using the 'envfit' function. Distance matrices of plant composition and soil characteristics were also generated by calculating Bray-Curtis dissimilarity. The relationships of soil microbial composition or soil enzyme composition with soil characteristics and plant composition were explored with Mantel tests. The independent effects of soil characteristics and plant composition on soil microbial composition and soil enzyme composition were explored with partial Mantel tests by controlling plant composition and soil characteristics, respectively.

All statistical analyses were carried out in R 2.15.1 [47]. NMDS and 'envfit' were carried out in the package Vegan [48]. Mantel and partial Mantel tests were carried out in the package Ecodist [49].

\section{Results}

\subsection{Soil characteristics and plant community}

One-way ANOVA indicated that soil $\mathrm{NO}_{3}{ }^{-}-\mathrm{N}(F=65.89, P$ $<0.001)$, total $\mathrm{P}(F=41.67, P<0.001), \mathrm{SOM}(F=16.11, P$ $=0.001)$, total $\mathrm{N}(F=9.47, P=0.001)$ and available $\mathrm{P}(F=$ $5.55, P=0.01)$ contents were significantly different among the NI, MI and $\mathrm{HI}$, but the $\mathrm{NH}_{4}{ }^{+}-\mathrm{N}$ content and $\mathrm{pH}$ were not significantly different. For example, total $\mathrm{P}$ and $\mathrm{NO}_{3}{ }^{-}-\mathrm{N}$ contents were significantly higher in $\mathrm{HI}$ than in $\mathrm{MI}$ and $\mathrm{NI}$, whereas SOM content was significantly lower in HI than in MI and NI (Table 1). The total N content was significantly higher in NI than in MI and $\mathrm{HI}$. The available $\mathrm{P}$ content was significantly higher in NI than in MI, but there was no significant difference between $\mathrm{NI}$ and $\mathrm{HI}$ and between $\mathrm{MI}$ and HI (Table 1).

NMDS analysis indicated that E. adenophorum invasion significantly influenced plant composition $\left(r^{2}=0.53, P=\right.$ $0.001)$. For example, the abundance of Hypericum acmosepalum, M. Africana, Rhododendron speciferum, Rubus foliolosus, and Tetrastigma obovatum was significantly decreased by E. adenophorum invasion (Table 2).

\subsection{Soil microbial biomass and composition}

In total, 30 PLFAs characterizing soil microbes were obtained, including 12:0, i12:0, 13:0, a13:0, 14:0, i14:0,

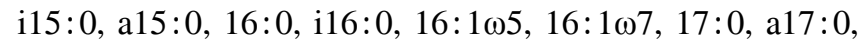

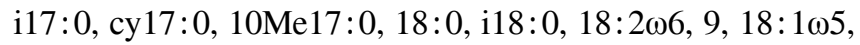
$18: 1 \omega 6,18: 1 \omega 7,18: 1 \omega 8,18: 1 \omega 9,18: 1 \omega 10,10 \mathrm{Me} 18: 0$, cy19:0, br19:0, 20:0. Within the 30 PLFAs, 22 were used 
Table 1 Soil characteristics in the different Eupatorium adenophorum invaded sites

\begin{tabular}{|c|c|c|c|}
\hline Variable & $\mathrm{NI}^{\mathrm{a})}$ & $\mathrm{MI}^{\mathrm{b})}$ & $\mathrm{HI}^{\mathrm{c})}$ \\
\hline Soil organic matter $\left(\mathrm{SOM}, \mathrm{g} \mathrm{kg}^{-1}\right)$ & $47.02 \pm 6.27 \mathrm{a}$ & $43.85 \pm 1.32 \mathrm{a}$ & $31.66 \pm 2.41 \mathrm{~b}$ \\
\hline Total $\mathrm{N}\left(\mathrm{g} \mathrm{kg}^{-1}\right)$ & $1.77 \pm 0.25 \mathrm{a}$ & $1.43 \pm 0.04 \mathrm{~b}$ & $1.40 \pm 0.03 b$ \\
\hline $\mathrm{NO}_{3}^{-}-\mathrm{N}\left(\mathrm{mg} \mathrm{kg}^{-1}\right)$ & $3.01 \pm 0.42 \mathrm{a}$ & $2.46 \pm 0.41 \mathrm{a}$ & $8.08 \pm 1.32 b$ \\
\hline $\mathrm{NH}_{4}^{+}-\mathrm{N}\left(\mathrm{mg} \mathrm{kg}^{-1}\right)$ & $9.31 \pm 0.62 \mathrm{a}$ & $9.88 \pm 0.65 \mathrm{a}$ & $8.29 \pm 1.34 \mathrm{a}$ \\
\hline Total $\mathrm{P}\left(\mathrm{g} \mathrm{kg}^{-1}\right)$ & $0.59 \pm 0.02 \mathrm{a}$ & $0.48 \pm 0.03 \mathrm{a}$ & $0.76 \pm 0.08 \mathrm{~b}$ \\
\hline Available $\mathrm{P}\left(\mathrm{mg} \mathrm{kg}^{-1}\right)$ & $5.93 \pm 0.12 \mathrm{a}$ & $4.27 \pm 0.75 b$ & $5.10 \pm 0.50 \mathrm{ab}$ \\
\hline $\mathrm{pH}$ value & $6.57 \pm 0.15 \mathrm{a}$ & $6.31 \pm 0.13 \mathrm{a}$ & $6.56 \pm 0.16 \mathrm{a}$ \\
\hline
\end{tabular}

a) no E. adenophorum invaded site; b) E. adenophorum moderately invaded site; c) E. adenophorum heavily invaded site. Values are means \pm SE of 3 replicates. Values with different letters in the same row indicate significant difference at $P<0.05$.

Table 2 Plant abundance in the different Eupatorium adenophorum invaded sites

\begin{tabular}{|c|c|c|c|}
\hline Plant species & $\mathrm{NI}^{\mathrm{a})}$ & $\mathrm{MI}^{\mathrm{b})}$ & $\mathrm{HI}^{\mathrm{c})}$ \\
\hline Alnus nepalensis D. Don & $2.4 \pm 1.0$ & $0.7 \pm 0.5$ & $0.8 \pm 0.5$ \\
\hline Buddleja officinalis Maxim. & $1.3 \pm 0.9$ & $0.0 \pm 0.0$ & $0.0 \pm 0.0$ \\
\hline Coniogramme intermedia Hieron. & $0.0 \pm 0.0 \mathrm{a}$ & $0.0 \pm 0.0 \mathrm{a}$ & $3.9 \pm 0.9 b$ \\
\hline Cornus capitata Wall. & $1.9 \pm 1.2$ & $0.0 \pm 0.0$ & $0.0 \pm 0.0$ \\
\hline Cotoneaster microphyllus Wall. ex Lindl. & $0.0 \pm 0.0 \mathrm{a}$ & $3.9 \pm 1.6 b$ & $1.3 \pm 0.9 \mathrm{ab}$ \\
\hline Cupressus duclouxiana Hickel & $0.0 \pm 0.0 \mathrm{a}$ & $5.8 \pm 1.2 \mathrm{~b}$ & $2.7 \pm 1.1 \mathrm{a}$ \\
\hline Echinochloa colonum (Linn.) Link & $0.7 \pm 0.5$ & $1.9 \pm 1.0$ & $0.3 \pm 0.2$ \\
\hline Elsholtzia ciliata (Thunb.) Hyland. & $1.2 \pm 0.8$ & $0.0 \pm 0.0$ & $0.0 \pm 0.0$ \\
\hline Eupatorium adenophorum Spreng. & $0.0 \pm 0.0 \mathrm{a}$ & $52.0 \pm 2.6 \mathrm{~b}$ & $98.4 \pm 1.8 \mathrm{c}$ \\
\hline Hypericum acmosepalum N. Robson & $2.7 \pm 0.7 \mathrm{a}$ & $0.5 \pm 0.3 b$ & $0.0 \pm 0.0 \mathrm{~b}$ \\
\hline Ilex chamaebuxus C.Y. Wu ex Y.R. Li & $6.1 \pm 2.6$ & $3.9 \pm 2.0$ & $0.0 \pm 0.0$ \\
\hline Lindera communis Hemsl. & $3.8 \pm 2.6$ & $0.0 \pm 0.0$ & $0.0 \pm 0.0$ \\
\hline Michelia yunnanensis Franch. ex Finet \& Gagnep. & $0.0 \pm 0.0$ & $0.0 \pm 0.0$ & $1.3 \pm 0.9$ \\
\hline Microstegium ciliatum A. Camus & $1.6 \pm 0.6$ & $1.8 \pm 1.2$ & $1.2 \pm 0.5$ \\
\hline Myrsine africana $\mathrm{L}$. & $70.2 \pm 3.6 \mathrm{a}$ & $13.2 \pm 1.9 \mathrm{~b}$ & $7.5 \pm 1.5 b$ \\
\hline Osyris wightiana Wall. ex Wight & $0.0 \pm 0.0$ & $0.0 \pm 0.0$ & $2.2 \pm 1.5$ \\
\hline Pinus armandii Franch. & $0.0 \pm 0.0$ & $1.0 \pm 0.7$ & $1.3 \pm 0.9$ \\
\hline Pinus yunnanensis Franch. & $1.2 \pm 0.8$ & $2.0 \pm 0.8$ & $1.3 \pm 0.9$ \\
\hline Prinsepia utihis Royle & $0.0 \pm 0.0$ & $2.8 \pm 1.2$ & $3.4 \pm 1.7$ \\
\hline Pyracantha fortuneana (Maxim.) H.L. Li & $1.8 \pm 1.2$ & $0.0 \pm 0.0$ & $0.0 \pm 0.0$ \\
\hline Quercus variabilis Blume & $0.0 \pm 0.0$ & $2.4 \pm 1.6$ & $1.3 \pm 0.9$ \\
\hline Rhododendron speciferum Franch. & $9.4 \pm 1.6 \mathrm{a}$ & $1.1 \pm 0.6 b$ & $3.3 \pm 1.8 b$ \\
\hline Rosa longicuspis Bertol. & $5.1 \pm 3.4$ & $1.4 \pm 0.9$ & $0.0 \pm 0.0$ \\
\hline Rubus foliolosus D. Don & $3.7 \pm 1.6 \mathrm{a}$ & $0.6 \pm 0.4 \mathrm{~b}$ & $0.0 \pm 0.0 \mathrm{~b}$ \\
\hline Rumex hastatus D. Don & $3.1 \pm 1.5 \mathrm{ab}$ & $4.0 \pm 1.2 \mathrm{a}$ & $0.0 \pm 0.0 \mathrm{~b}$ \\
\hline Setaria plicata T. Cooke & $2.3 \pm 0.8 \mathrm{a}$ & $2.6 \pm 1.0 \mathrm{a}$ & $0.0 \pm 0.0 \mathrm{~b}$ \\
\hline Tetrastigma obovatum (Laws.) Gagnep. & $1.9 \pm 0.8 \mathrm{a}$ & $0.0 \pm 0.0 \mathrm{~b}$ & $0.0 \pm 0.0 \mathrm{~b}$ \\
\hline Viburnum foetidum Wall. & $0.0 \pm 0.0$ & $5.1 \pm 2.1$ & $2.7 \pm 1.8$ \\
\hline Total abundance & $120.0 \pm 6.0 \mathrm{a}$ & $106.7 \pm 9.9 \mathrm{~b}$ & $133.3 \pm 5.0 \mathrm{c}$ \\
\hline Species richness & $7.2 \pm 1.2 \mathrm{ab}$ & $8.2 \pm 1.5 \mathrm{a}$ & $6.2 \pm 1.3 \mathrm{~b}$ \\
\hline
\end{tabular}

a) no E. adenophorum invaded site; b) E. adenophorum moderately invaded site; c) E. adenophorum heavily invaded site. Values are means \pm SE of 3 replicates. Values with different letters in the same row indicate significant difference at $P<0.05$.

to indicate taxonomic microbial groups, in which $\mathrm{G}^{+}$were represented by nine, $\mathrm{G}^{-}$by eight, actinomycetes by two, AMF by one, and fungi by two (excluding AMF) (Table 3 ). The biomass of total microbes $(F=15.09, P<0.001), \mathrm{G}^{-}(F$ $=29.97, P<0.001)$, actinomycetes $(F=14.19, P<0.001)$, $\operatorname{AMF}(F=5.65, P=0.015)$ and fungi $(F=30.99, P<0.001)$ were significantly higher in NI than in MI and HI, but there was no significant difference between MI and HI (Figure 1). In addition, the biomass of $\mathrm{G}^{+}(F=6.26, P=0.011)$ was significantly lower in MI than in NI and HI, but there was no significant difference between NI and HI (Figure 1).

NMDS analysis demonstrated that soil microbial composition was significantly different among the NI, MI and HI $\left(r^{2}=0.53, P=0.001\right.$ in envfit, Figure 2(a)). Furthermore, the soil microbial composition was significantly related to available $\mathrm{P}\left(r^{2}=0.45, P=0.002\right)$, total $\mathrm{N}\left(r^{2}=0.38, P=\right.$ $0.004)$, total $\mathrm{P}\left(r^{2}=0.27, P=0.015\right)$, and seven plant species: E. adenophorum $\left(r^{2}=0.63, P=0.001\right)$, M. africana $\left(r^{2}\right.$ 
Table 3 Phospholipid fatty acid (PLFA) markers used for taxonomic microbial groups in this study

\begin{tabular}{ll}
\hline \multicolumn{1}{c}{ Microbial group } & \multicolumn{1}{c}{ Specific PLFA marker } \\
\hline Gram-negative bacteria $\left(\mathrm{G}^{-}\right)$ & Sum of $16: 1 \omega 7$, cy $17: 0,18: 1 \omega 5,18: 1 \omega 6,18: 1 \omega 7,18: 1 \omega 8,18: 1 \omega 10$, and cy $19: 0$ \\
Gram-positive bacteria $\left(\mathrm{G}^{+}\right)$ & Sum of i12:0, a13:0, i14:0, i15:0, a15:0, i16:0, a17:0, i17:0, and i18:0 \\
Actinomycetes & Sum of $10 \mathrm{Me} 17: 0$ and $10 \mathrm{Me} 18: 0$ \\
Arbuscular mycorrhizal fungi (AMF) & $16: 1 \omega 5$ \\
Fungi (excluding AMF) & Sum of $18: 2 \omega 6,9$ and $18: 1 \omega 9$ \\
\hline
\end{tabular}

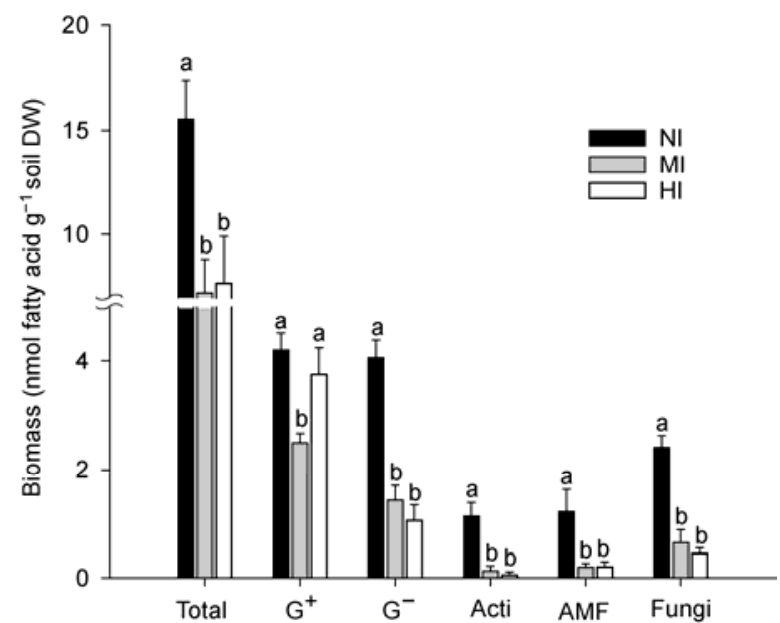

Figure 1 Biomass of soil microbes in the different Eupatorium adenophorum invaded sites. Bars with different letters indicate significant difference at $P<0.05$. NI, no E. adenophorum invaded site; MI, E. adenophorum moderately invaded site; HI, E. adenophorum heavily invaded site; Total, total soil microbes; $\mathrm{G}^{+}$, Gram-positive bacteria; $\mathrm{G}^{-}$, Gram-negative bacteria; Acti, actinomycetes; AMF, arbuscular mycorrhiza fungi; Fungi, fungi (excluding AMF).

$=0.60, P=0.001), H$. acmosepalum $\left(r^{2}=0.41, P=0.002\right)$, $R$. speciferum $\left(r^{2}=0.38, P=0.003\right)$, Michelia yunnanensis $\left(r^{2}=0.31, P=0.009\right)$, Cotoneaster microphyllus $\left(r^{2}=0.27\right.$, $P=0.013)$ and Pinus armandii $\left(r^{2}=0.26, P=0.014\right)$.

Mantel tests indicated that soil microbial composition

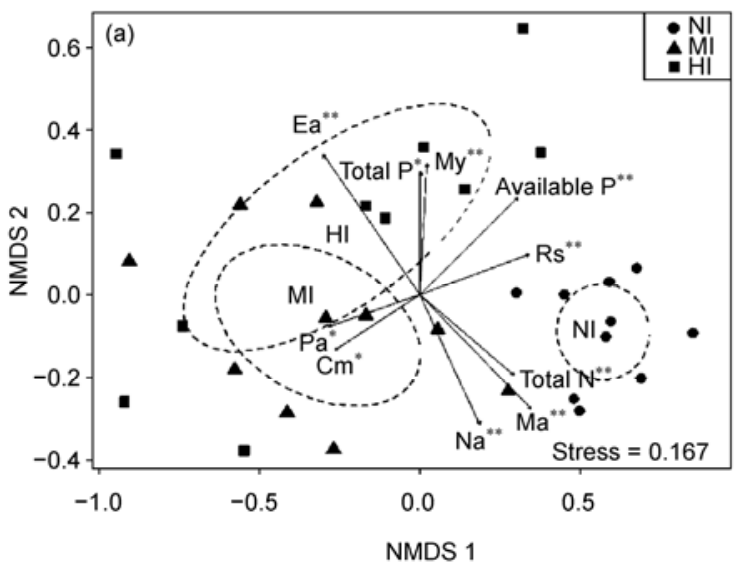

was significantly correlated with plant composition $(r=$ $0.47, P=0.001$, Table 4). Furthermore, plant composition was still significant after the effect of soil characteristics variables was controlled for by partial Mantel tests $(r=0.48$, $P=0.001)$. Soil characteristics exhibited no significant influence on microbial composition (Table 4).

\subsection{Soil enzyme activity and composition}

One-way ANOVA indicated that polyphenol oxidase $(F=$ 69.66, $P<0.001)$, peroxidase $(F=40.27, P<0.001)$, urease $(F=26.24, P<0.001)$ and acid phosphatase $(F=3.52, P=$ 0.044 ) activities were significantly different among the NI, MI and HI. For example, urease and acid phosphatase activities were significantly higher in HI than in NI and MI, but there was no significant difference between NI and MI (Figure 3). Polyphenol oxidase and peroxidase activities significantly increased with invasion intensity of $E$. adenophorum. However, the activities of invertase, $\beta$-glucosidase, cellulase and alkaline phosphatase were not significantly different among the NI, MI and HI (Figure 3).

NMDS analysis showed that soil enzyme composition was significantly different among the NI, MI and $\mathrm{HI}\left(r^{2}=\right.$ $0.68, P=0.001$ in envfit, Figure 2(b)). Furthermore, the soil enzyme composition was significantly related to $\mathrm{NO}_{3}^{-}-\mathrm{N}\left(r^{2}\right.$ $=0.55, P=0.001)$, total $\mathrm{P}\left(r^{2}=0.45, P=0.001\right)$, total N $\left(r^{2}\right.$ $=0.26, P=0.026)$, and seven plant species $E$. adenophorum

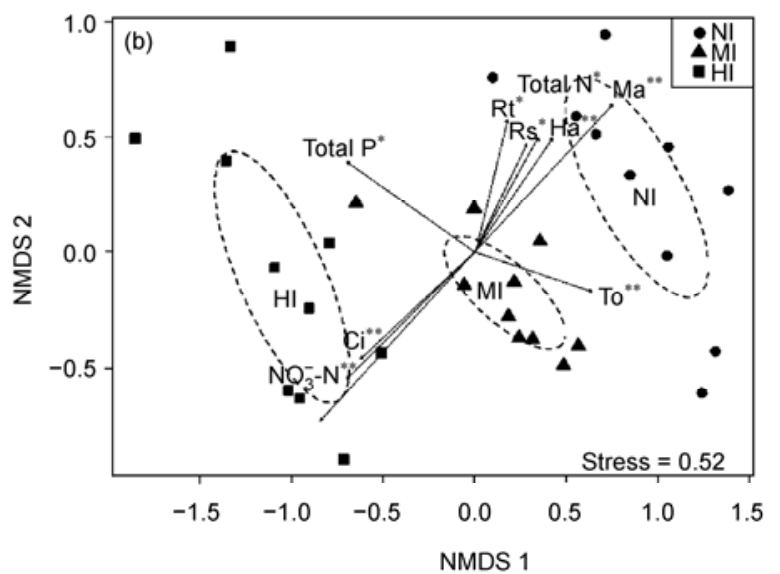

Figure 2 Non-metric multidimensional scaling (NMDS) ordinations of (a) soil microbial composition $\left(r^{2}=0.53, P=0.001\right)$ and (b) soil enzyme composition $\left(r^{2}=0.68, P=0.001\right)$ of all plots. Vectors shown on the ordination plots were significant at $* P<0.05$ and $* * P<0.01$. NI, no E. adenophorum invaded site; MI, E. adenophorum moderately invaded site; HI, E. adenophorum heavily invaded site; Ci, Coniogramme intermedia; Cm, Cotoneaster microphyllus; Ea, Eupatorium adenophorum; Ha, Hypericum acmosepalum; Ma, Myrsine africana; My, Michelia yunnanensis; Pa, Pinus armandii; Rf, Rubus foliolosus; Rs, Rhododendron speciferum; To, Tetrastigma obovatum. 
Table 4 Mantel and partial Mantel tests of soil microbial composition and enzyme composition with plant composition and soil parameters

\begin{tabular}{|c|c|c|c|c|c|c|c|c|}
\hline & \multicolumn{4}{|c|}{ Plant composition } & \multicolumn{4}{|c|}{ Soil characteristics } \\
\hline & \multicolumn{2}{|c|}{ Mantel test } & \multicolumn{2}{|c|}{ Partial Mantel test ${ }^{\mathrm{a})}$} & \multicolumn{2}{|c|}{ Mantel test } & \multicolumn{2}{|c|}{ Partial Mantel test } \\
\hline & $r$ & $P$ & $r$ & $P$ & $r$ & $P$ & $r$ & $P$ \\
\hline Microbial composition & 0.47 & 0.001 & 0.48 & 0.001 & 0.09 & 0.107 & -0.12 & 0.971 \\
\hline Soil enzymes & 0.56 & 0.001 & 0.49 & 0.001 & 0.17 & 0.029 & -0.07 & 0.785 \\
\hline
\end{tabular}

a) Plant composition was partialled out when calculating partial Mantel $r$ of soil characteristics, and soil characteristics was partialled out when calculating partial Mantel $r$ of plant composition.

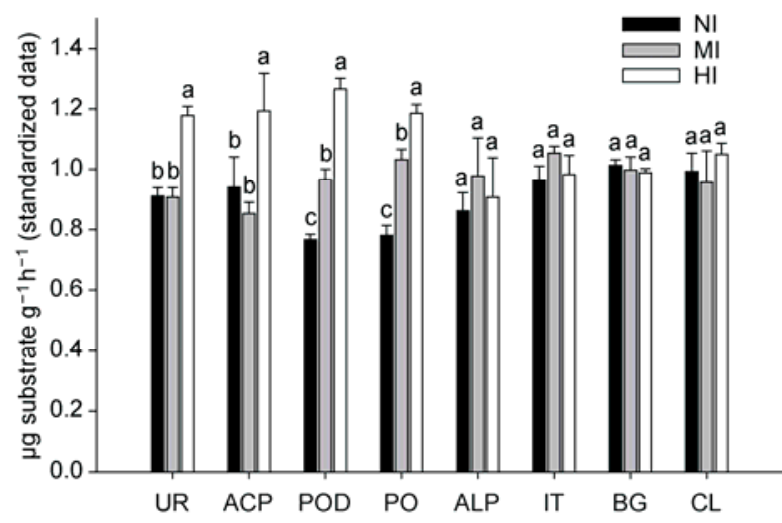

Figure 3 Soil enzyme activities in the different Eupatorium adenophorum invaded sites. Bars with different letters indicate significant difference at $P<0.05$. NI, no E. adenophorum invaded site; MI, E. adenophorum moderately invaded site; HI, E. adenophorum heavily invaded site; UR, urease; ACP, acid phosphatase; PPO, polyphenol oxidase; PO, peroxidase; ALP, alkaline phosphatase; IT, invertase; BG, $\beta$-glucosidase; CL, cellulase.

$\left(r^{2}=0.87, P=0.001\right), M$. africana $\left(r^{2}=0.68, P=0.001\right)$, Coniogramme intermedia $\left(r^{2}=0.42, P=0.001\right), H$. acmosepalum $\left(r^{2}=0.33, P=0.006\right), T$. obovatum $\left(r^{2}=0.31, P=\right.$ $0.003), R$. foliolosus $\left(r^{2}=0.25, P=0.015\right)$ and $R$. speciferum $\left(r^{2}=0.21, P=0.038\right)$.

Mantel tests indicated that soil enzyme composition was significantly correlated with soil characteristics $(r=0.17, P$ $=0.029)$ and plant composition $(r=0.56, P=0.001$, Table $4)$. Furthermore, plant composition was still significant after the effect of soil characteristics variables was controlled for by partial Mantel tests $(r=0.49, P=0.001)$, but soil characteristics exhibited no significant influence after the effect of plant composition was partialled out (Table 4).

\section{Discussion and conclusions}

The biomass of total soil microbes and major microbial groups were significantly lower in E. adenophorum invaded sites than in the no E. adenophorum invaded site in this study. Similarly, fungal biomass was reduced by invasion of Berberis thunbergii [10] and Cenaurea maculosa [50], and the biomass of AMF was decreased by Alliaria petiolata invasion [19] in sites in North America. Furthermore, our results showed that the soil microbial composition was significantly different in the three E. adenophorum invaded sites, agreeing with previous studies that bacterial composition was significantly different between lightly and heavily E. adenophorum invaded sites in China $[31,32]$. Similarly, soil microbial compositions were dramatically altered by the invasion of the exotic plants B. thunbergii in New Jersey [10], Mikania micrantha in southeast China [12], Falcataria moluccana in Hawaii [51], Centaurea solstitialis and Aegilops triuncialis in Northern California [52], and Lonicera maackii in Kentucky [8].

Soil microbial community can be directly shaped by allelopathy of exotic plants [5,53]. Eupatorium adenophorum, as a strong allelopathic plant [28-30], can release some chemical compounds that have significant antibacterial and antifungal effects [54], which can decrease soil microbial biomass and alter microbial composition. In addition, our results indicated that $E$. adenophorum invasion significantly influenced plant communities, which are likely to produce litter, root exudates and organic matter that differ in their chemical composition and role in maintaining nutrient pools. Therefore, the soil microbial community could be indirectly affected by E. adenophorum invasion via changing the local plant community [53,55].

Soil enzyme composition was significantly different in the three E. adenophorum invaded sites in this study. Similarly, some previous studies have reported that soil enzyme compositions were significantly changed by the exotic plant M. micrantha invasion in southeast China [12] and B. thunbergii in New Jersey [10]. Furthermore, soil enzyme composition was significantly correlated with plant composition in our study. Plant released-compounds such as polysaccharides, aromatic compounds and esters, together with detritus and root exudates serve as sources of substrates for enzymatic degradation and provide the energy and elements' necessary for enzyme synthesis [56]. Thus, variation in plant inputs to soil, which arise from changes in plant composition by $E$. adenophorum invasion, has the potential to cause variation in enzyme composition [56].

Urease and acid phosphatase activities were significantly higher in the site heavily invaded with E. adenophorum compared with the moderately and no invaded sites. Similarly, urease and acid phosphatase activities were increased by $M$. micrantha invasion in southeast China [12] and $F$. moluccana invasion in Hawaii [51]. Elevated activities of related $\mathrm{P}$ and $\mathrm{N}$ degrading enzymes in the invaded sites indicated that $E$. adenophorum may accelerate nutrient 
mineralization rates of organic $\mathrm{P}$ and $\mathrm{N}$ [12,51]. In addition, the polyphenol oxidase and peroxidase activities were significantly increased with invasion intensity of E. adenophorum. Similarly, phenol oxidase activity was increased by the invasion of $M$. micrantha in southeast China [12] and $B$. thunbergii in New Jersey [10]. These oxidative enzyme activities, degrading more complex materials, often correlate with high decomposition rate and mass loss rate in SOM [57], which is consistent with our result that SOM content significantly decreased with $E$. adenophorum invasion. In addition, $E$. adenophorum invasion did not significantly influence the activities of alkaline phosphatase, $\beta$-glucosidase, cellulase, and invertase in the present study. Previous studies also have reported some inconsistent results of these enzyme activities affected by different exotic plants. For example, alkaline phosphatase and $\beta$-glucosidase activities were significantly decreased by $B$. thunbergii invasion in New Jersey [10], whereas they were significantly increased by $M$. micrantha invasion in southeast China [12]. It suggests that soil enzymes show various responses to different exotic plant invasions in ecosystems.

In addition, some soil chemical properties were significantly different in the three E. adenophorum invaded sites. For example, the total $\mathrm{P}$ and $\mathrm{NO}_{3}{ }^{-}-\mathrm{N}$ contents were significantly higher whereas the total $\mathrm{N}$ content was significantly lower in E. adenophorum invaded sites than in the no $E$. adenophorum invaded site. The results are consistent with other studies that found similar changes in soil properties with exotic plant invasion [58-60]. For example, Amaranthus viridis invasion significantly increased concentration of soil total P in Senegal [58], and Agropyron cristatum invasion decreased total $\mathrm{N}$ at the northern edge of the Great Plains, USA [59]. Soil $\mathrm{NO}_{3}{ }^{-}-\mathrm{N}$ content was $30 \%$ higher in invaded ecosystems than in native ecosystems based on the meta-analysis of 94 experimental studies [60]. The reason for the differences in soil chemical property might be the effect of E. adenophorum invasion or also might be a spatial heterogeneity effect. Furthermore, there was a reverse changing trend between microbial biomass and some soil enzyme activities with increasing E. adenophorum invasion. This is because soil enzymes not only come from living and dead microbes, but also from plant roots and residues and soil animals. Enzymes stabilized in the soil matrix accumulate or form complexes with humus, clay, and humus-clay complexes. It is thought that $40 \%$ to $60 \%$ of enzyme activity can come from stabilized enzymes, thus soil enzyme activity does not necessarily correlate highly with microbial biomass [61].

In conclusion, E. adenophorum invasion conspicuously influenced local plant species composition and some soil properties such as $\mathrm{NO}_{3}{ }^{-}-\mathrm{N}$, total $\mathrm{N}$, available $\mathrm{P}$, total $\mathrm{P}$ and SOM contents. The soil microbial composition and soil enzyme composition were significantly different in the three $E$. adenophorum invaded sites. Furthermore, there were inversely changing trends between microbial biomass and some soil enzyme activities with increasing E. adenophorum invasion. Plant composition was the most important factor for structuring soil microbial and enzyme compositions. Our results suggest that changes in soil microbial community structure and enzyme activity may play an important role in the invasive process of E. adenophorum in a southwest Chinese secondary forest. However, we also recognize that further studies, concerning more exotic plant species in wide geographic scales, will promote our understanding of the mechanism of exotic plant invasive processes in natural ecosystems.

We thank Yang Wei, Institute of Microbiology, Chinese Academy of Sciences for sample collection, and Lu Zhenghong, Yunnan University for plant investigation. Thanks also to Dr. Jo Taylor, Royal Botanic Garden Edinburgh for English revision and comments. This work was supported by National Natural Science Foundation of China (30870087 and 31070434).

1 Moles A T, Flores-Moreno H, Bonser S P, et al. Invasions: The trail behind, the path ahead, and a test of a disturbing idea. J Ecol, 2012, 100: $116-127$

2 Pejchar L, Mooney H A. Invasive species, ecosystem services and human well-being. Trends Ecol Evol, 2009, 24: 497-504

3 Levine J M, Vila M, D'Antonio C M, et al. Mechanisms underlying the impacts of exotic plant invasions. Proc R Soc Lond B, 2003, 270: 775-781

4 van der Heijen M G A. The unseen majority: Soil microbes as drivers of plant diversity and productivity in terrestrial ecosystems. Ecol Lett, 2008, 11: 651

5 Wolfe B E, Klironomos J N. Breaking new ground: Soil communities and exotic plant invasion. Bioscience, 2005, 55: 477-487

6 Callaway R M, Thelen G C, Rodriguez A, et al. Soil biota and exotic plant invasion. Nature, 2004, 427: 731-733

7 Wilson G W T, Hickman K R, Williamson M M. Invasive warmseason grasses reduce mycorrhizal root colonization and biomass production of native prairie grasses. Mycorrhiza, 2012, 22: 327-336

8 Arthur M A, Bray S R, Kuchle C R, et al. The influence of the invasive shrub, Lonicera maackii, on leaf decomposition and microbial community dynamics. Plant Ecol, 2012, 213: 1571-1582

9 Elgersma K J, Ehrenfeld J G. Linear and non-linear impacts of a non-native plant invasion on soil microbial community structure and function. Biol Invasions, 2011, 13: 757-768

10 Kourtev P S, Ehrenfeld J G, Haggblom M. Exotic plant species alter the microbial community structure and function in the soil. Ecology, 2002, 83: 3152-3166

11 Lankau R A. Resistance and recovery of soil microbial communities in the face of Alliaria petiolata invasions. New Phytol, 2011, 189: 536-548

12 Li W H, Zhang C B, Jiang H B, et al. Changes in soil microbial community associated with invasion of the exotic weed, Mikania micrantha H.B.K. Plant Soil, 2006, 281: 309-324

13 Lorenzo P, Rodriguez-Echeverria S, Gonzalez L, et al. Effect of invasive Acacia dealbata Link on soil microorganisms as determined by PCR-DGGE. Appl Soil Ecol, 2010, 44: 245-251

14 Blumenthal D, Mitchell C E, Pysek P, et al. Synergy between pathogen release and resource availability in plant invasion. Proc Natl Acad Sci USA, 2009, 106: 7899-7904

15 Reinhart K O, Packer A, Van der Putten W H, et al. Plant-soil biota interactions and spatial distribution of black cherry in its native and invasive ranges. Ecol Lett, 2003, 6: 1046-1050

16 Beckstead J, Meyer S E, Connolly B M, et al. Cheatgrass facilitates spillover of a seed bank pathogen onto native grass species. J Ecol, 2010, 98: 168-177

17 Mangla S, Inderjit, Callaway R M. Exotic invasive plant accumulates native soil pathogens which inhibit native plants. J Ecol, 2008, 96: 
$58-67$

18 Meinhardt K A, Gehring C A. Disrupting mycorrhizal mutualisms: A potential mechanism by which exotic tamarisk outcompetes native cottonwoods. Ecol Appl, 2012, 22: 532-549

19 Stinson K A, Campbell S A, Powell J R, et al. Invasive plant suppresses the growth of native tree seedlings by disrupting belowground mutualisms. PLoS Biol, 2006, 4: 727-731

20 Vogelsang K M, Bever J D. Mycorrhizal densities decline in association with nonnative plants and contribute to plant invasion. Ecology, 2009, 90: 399-407

21 Sun X Y, Lu Z H, Sang W G. Review on studies of Eupatorium adenophorum - an important invasive species in China. J Forest Res, 2004, 15: 319-322

22 Xie Y, Li Z Y, Gregg W P, et al. Invasive species in China - an overview. Biodivers Conserv, 2001, 10: 1317-1341

23 Wan F H, Liu W X, Guo J Y, et al. Invasive mechanism and control strategy of Ageratina adenophora (Sprengel). Sci China Life Sci, 2010, 53: 1291-1298

24 Li Y P, Feng Y L. Differences in seed morphometric and germination traits of crofton weed (Eupatorium adenophorum) from different elevations. Weed Sci, 2009, 57: 26-30

25 Lu H F, Shen J B, Sang W G, et al. Pollen viability, pollination, seed set, and seed germination of croftonweed (Eupatorium adenophorum) in China. Weed Sci, 2008, 56: 42-51

$26 \mathrm{Li} \mathrm{H}$, Qiang S, Qian Y L. Physiological response of different croftonweed (Eupatorium adenophorum) populations to low temperature. Weed Sci, 2008, 56: 196-202

27 Wang J F, Feng Y L, Liang H. Adaptation of Eupatorium adenophorum photosynthetic characteristics to light intensity (in Chinese). Chin J Appl Ecol, 2004, 15: 1373-1377

28 Xie L J, Zeng R S, Bi H H, et al. Allelochemical mediated invasion of exotic plants in China. Allelopathy J, 2010, 25: 31-50

29 Yu X J, Yu D, Ma K P. Relationships between allelophthy and invasiveness by Eupatorium adenophorum at different sites (in Chinese). Acta Phytoecol Sin, 2004, 28: 773-780

30 Zhu X Z, Zhang J T, Ma K P. Soil biota reduce allelopathic effects of the invasive Eupatorium adenophorum. PLoS ONE, 2011, 6: e25393

31 Yu X J, Yu D, Lu Z J, et al. A new mechanism of invader success: Exotic plant inhibits natural vegetation restoration by changing soil microbe community. Chin Sci Bull, 2005, 50: 1105-1112

32 Xu C W, Yang M Z, Chen Y J, et al. Changes in non-symbiotic nitrogen-fixing bacteria inhabiting rhizosphere soils of an invasive plant Ageratina adenophora. Appl Soil Ecol, 2012, 54: 32-38

33 Nelson D W, Sommers L E. Total carbon, organic carbon, and organic matter. In: Sparks D L, Page A L, Helmke P A, et al. eds. Methods of Soil Analysis. Part 3, Chemical Methods. Madison, WI: SSSA, 1996. 961-1010

34 Scheiner D. Determination of ammonia and Kjeldahl nitrogen by indophenol method. Water Res, 1976, 10: 31-36

35 Mulvaney R L. Nitrogen-inorganic forms. In: Sparks D L, Page A L, Helmke P A, et al. eds. Methods of Soil Analysis. Part 3, Chemical Methods. Madison, WI: SSSA, 1996. 1123-1184

36 Kuo S. Phosphorus. In: Sparks D L, Page A L, Helmke P A, et al. eds. Methods of Soil Analysis. Part 3, Chemical Methods. Madison, WI: SSSA, 1996. 869-919

37 Frostegård A, Tunlid A, Bååth E. Phospholipid fatty acid composition, biomass, and activity of microbial communities from 2 soil types experimentally exposed to different heavy metals. Appl Environ Microbiol, 1993, 59: 3605-3617

38 Frostegård A, Bååth E. The use of phospholipid fatty acid analysis to estimate bacterial and fungal biomass in soil. Biol Fert Soils, 1996, 22: 59-65
39 Zelles L. Fatty acid patterns of phospholipids and lipopolisaccharides in the characterisation of microbial communities: A review. Biol Fertil Soils, 1999, 29: 111-129

40 Olsson P A. Signature fatty acids provide tools for determination of the distribution and interactions of mycorrhizal fungi in soil. FEMS Microbiol Ecol, 1999, 29: 303-310

41 Kaiser C, Frank A, Wild B, et al. Negligible contribution from roots

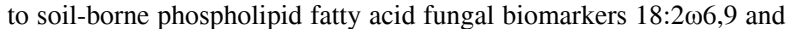
18:1 $\omega 9$. Soil Biol Biochem, 2010, 42: 1650-1652

42 Sinsabaugh R L, Antibus R K, Linkins A E, et al. Wood decomposition: Nitrogen and phosphorus dynamics in relation to extracellular enzyme activity. Ecology, 1993, 74: 1586-1593

43 Kandeler E, Gerber H. Short-term assay of soil urease activity using colorimetric determination of ammonium. Biol Fert Soils, 1988, 6: $68-72$

44 Schinner F, von Mersi W. Xylanase-, CM-cellulase- and invertase activity in soil: An improved method. Soil Biol Biochem, 1990, 22: $511-515$

45 Zhou L K, Zhang Z M. The determination method of soil enzyme activity (in Chinese). Chin J Soil Sci, 1980, 5: 37-49

46 Frostegård A, Tunlid A, Bååth E. Use and misuse of PLFA measurements in soils. Soil Biol Biochem, 2011, 43: 1621-1625

47 R Development Core Team. R: A Language and Environment for Statistical Computing. Vienna, Austria: R Foundation for Statistical Computing. 2011

48 Oksanen J, Kindt R, Legendre P, et al. The vegan package. http:// vegan.r-forge.r-project.org/. 2007

49 Goslee S C, Urban D L. The ecodist package for dissimilarity-based analysis of ecological data. J Stat Softw, 2007, 22: 1-19

50 Broz A K, Manter D K, Vivanco J M. Soil fungal abundance and diversity: Another victim of the invasive plant Centaurea maculosa. ISME J, 2007, 1: 763-765

51 Allison S D, Nielsen C, Hughes R F. Elevated enzyme activities in soils under the invasive nitrogen-fixing tree Falcataria moluccana. Soil Biol Biochem, 2006, 38: 1537-1544

52 Batten K M, Scow K M, Davies K F, et al. Two invasive plants alter soil microbial community composition in serpentine grasslands. Biol Invasions, 2006, 8: 217-230

53 Inderjit, van der Putten W H. Impacts of soil microbial communities on exotic plant invasions. Trends Ecol Evol, 2010, 25: 512-519

54 Arvind N, Amit S. Antimicrobial potential of Eupatorium adenophorum Spreng. Pharmacogn J, 2010, 2: 61-64

55 Eskelinen A, Stark S, Mannisto M. Links between plant community composition, soil organic matter quality and microbial communities in contrasting tundra habitats. Oecologia, 2009, 161: 113-123

56 Hernandez D L, Hobbie S E. The effects of substrate composition, quantity, and diversity on microbial activity. Plant Soil, 2010, 335: 397-411

57 Sinsabaugh R L. Phenol oxidase, peroxidase and organic matter dynamics of soil. Soil Biol Biochem, 2010, 42: 391-404

58 Sanon A, Béguiristain T, Cébron A, et al. Changes in soil diversity and global activities following invasions of the exotic invasive plant, Amaranthus viridis $\mathrm{L}$., decrease the growth of native sahelian Acacia species. FEMS Microbiol Ecol, 2009, 70: 118-131

59 Christian J M, Wilson S D. Long-term ecosystem impacts of an introduced grass in the northern Great Plains. Ecology, 1999, 80: 23972407

60 Liao C Z, Peng R H, Luo Y Q, et al. Altered ecosystem carbon and nitrogen cycles by plant invasion: A meta-analysis. New Phytol, 2008, 177: 706-714

61 Bandick A K, Dick R P. Field management effects on soil enzyme activities. Soil Biol Biochem, 1999, 31: 1471-1479

Open Access This article is distributed under the terms of the Creative Commons Attribution License which permits any use, distribution, and reproduction in any medium, provided the original author(s) and source are credited. 